植物繊維分解ルーメン細菌における遺伝子工学

大宮邦雄・荻田修一 ${ }^{*}$

三重大学生物資源学部，津市 514

*三重大学遺伝子実験施設，津市 514

\title{
Genetic Engineering of the Plant Fiber-degrading Rumen Bacteria
}

\author{
Kunio OHмiYa and Shuichi Karita* \\ Faculty of Bioresources, Mie University, Tsu-shi 514 \\ * Center for Molecular Biology and Geneties, Mie \\ University, Tsu-shi 514
}

Key words: genetic engineering, plant fiber degradation, rumen bacteria, cellulase, cloning

牛や羊のような反すう家畜は，人類に乳肉や毛皮を供 給し，労役を提供する重要な経済動物である，そのうえ 人や豚や鴙が利用し難い牧草等のリグノセルロース性物 啠を主たる飼料としているので，人類と食糧を争奪する 関係にない点でも極めて有用な家畜である。この反すう 家畜の生産性を高めるために近年わが国の畜産業は濃厚 飼料にかなり依存してきた，しかし生産コストの低減化 をせまられ地球規模での食料不足が予測される昨今にお いては，粗飼料の高度利用がみなおされ始めている，家 畜が摄取した粗飼料は，ルーメン内の嫌気性微生物群 （細菌，系状菌，原生動物）の相乗作用以上り可溶化さ れるので、これら微生物のリグノセルロース分解能を改 良することに大きな関心が句けられている。なかでもセ ルロース分解嫌気性細菌の果たす役割は特に重要であろ う.

一方大腸菌で始まった逶伝子組換えは，この10年間 で簡便普遍化した技術として確立され，単に原核細胞の DNA 組換えにとよ゙まらず植物や動物といった真核細胞 あ広く利用されるようになり，いわゆる生物の研究には

日畜会報，63(5)：520-536
不可欠な手段となっている，その結果，分子育種という 新たな学問領域をつくるに至った。このおかげでわれわ 机が希望す石機能の高い形澌を導入した新奇な生物を育 種することが可能となってきた。

こういった状洗のなかで，セルロース分解能を高めた ルーメン細菌の能種を考える時，セルラーゼに関連する 醉素群の遺伝子組換えに関心があたれるのは当然の成り ゆきであろう。それではルーメン菌の遭伝子組換えによ りどのようなことが期待できるであろうか.

1. 植物繊維分解効率の向上.（ルーメン菌のセルロ 一ス性物買の分解能力を付与改善する。例えばセルロ一 スあるいはヘミセルロース分解醉素遺伝子を新たに導入 したり，在来遺伝子の発現量を多くする．また生成物阻 害を受けにくい酵素の遗伝子を導入する.)

2. 窒素の利用率の向上.（プロテアーゼ生産菌やウ レアーゼ生産菌の生産能を下げたり，あるいは必須アミ 八酸の合成系を強化する.)

3、抗生物質生産能の付与。（病原微生物の生育を揤 える. 例えば真核生物に対する抗菌物犋をルーメン細菌 20 1992 
植物瀻維分解ルーメン細菌におりる遺伝子工学

に生座させることにより，抗生物質の経口投与量を减ら す．またセルロース分解菌に抗生物質耐性能を付与しま. 要菌叢とする。生育の早い乳酸生産菌を㧕制する。) などが考えられている ${ }^{10,19,27,73,85) . ~}$

ルーメン細菌の遗伝子組換えに関する研究はまだ緒に ついたばかりである，それであ遗伝子組換え技術の活用 により，ルーメン細菌の植物織維分解機能の改良に関す る新たな知見がいくつか得られている，例えば Ruminococcus albus や Fibrobactor succinogenes では, 数種のエンドグルカナーゼの存在が明らかになり，従来 の生化学的精製法だけでは検出されていなかった醉素が, クローニングにより大腸菌で発現増幅され，あるいは抗 体によるイムノブロットにより，新たなセルラーゼの存 在が確認されている．このように発現量が少なく見のが されてきた酵素がクローニングにより新たに発見された り，それらの醉素の存在場所や発現時期なども明らかに なりつつありこれららのルーメン細菌内での発現を爆発 的に高めうる可能性すでてきた。

この総説では，これらルーメン細菌の植物䌜維分解に 関わる醅素の遭伝子組換えについて紹介するととすに， ルーメン細菌のセルロース分解機能を改良するために新 たなる宿主べクター系の開発についてもふれる。

\section{植物䋐維分解酵素遺伝子のクローニング}

植物䋐維分解に関わるルーメン微生物の醉素系は一般 に複数の酵素群で構成されており，段階的および相乗的 作用を発揮している，現在までに表 1 に示す酵素が単㒕 されている，大きくセルラーゼ系とへミセルラーゼ系に 分けられる. セルラーゼ系の場合，エキソグルカナーゼ， エンドグルカナーゼ, $\beta$ ターグルコシダーゼの 3 つのタイ ブがある. エキングルカナーゼはセルロースを非還元末 端よりセロビオース単位で分解する、エンドグルカナー ゼはせルロースの非結晶部をランダムに切り，エキング ルカナーゼの基質となるような多くの非還元末端を生じ る. $\beta$ グルコシダーゼはこれらの酵素より生じたセロ ビオースやセロデキストリンをグルコースに分解する. ここに至ってはじめてグルコースの代謝系が働くことに なる、キシラナーゼに代表されるへミセルラーゼ系につ いても同栐の醉素系が知られている。このような醉素系 をさらに調べてみると同じェンドグルカナーゼの中に あ複数の酳素が存在しているこ上が最近あきらかになっ てきた。このような例は Clostridium thermocellum $^{3,744}$ などであ報告されている。このことは，多様な 成分上りなり分解に時間のかかる植物紷維を多種の醉素 の相乗的作用により効率的に分解可溶化するために必要
Table 1. Rumen bacterial enzymes participating in polysaccharide digestion

\begin{tabular}{lc}
\hline \hline \multicolumn{1}{c}{ Enzyme } & References \\
\hline Endoglucanase & $13,51,65,92$. \\
Exoglucanase & $21,35,63$ \\
$\beta$-Glucosidase & 64 \\
Cellodextrinase & 33,34 \\
Xylanase & 28 \\
Xylosidase & 99 \\
Acetyl xylan esterase & 29,50 \\
Acetyl esterase & 29,50 \\
$\boldsymbol{\alpha}$-L-Arabinofuranosi dase & 89 \\
Amylase & 11 \\
Arabinase & 99 \\
Laminarinase & 16 \\
Lichenase & 15 \\
Pectinase & 99 \\
$\boldsymbol{\alpha}$-Glucuronidase & 80 \\
\hline
\end{tabular}

なのであろうと考えている ${ }^{87) . ~}$

現在までに多くの植物紻䧽分解に関わる醉素の遗伝子 がルーメン細菌より単離され，これにコードされる酵素 が大腸菌て人為的に増やされている，すなわちクロ一二 ングされている，クローンとは，あるひとつの細胞や分 子を先祖とし，それ之完全に同じ細胞や分子の一群と定 義される ${ }^{422}$. 従って DNA の断片をクローニングする と，元の分子がただ1個であってもこの分子から同一の 分子を無限に增や方ことができる。一度クローニングさ れた DNA 断片は增やされ解析することが可能になる。 例えば塩基配列を決定することでその DNA がどのよ うなアミ/酸配列の蛋白質（醉素）をコードしているか を，全アミ/酸のシークエンスを決定することなく谷易 に推定することができる，クローニング技術は，まず目 的の DNA 断片をクローニングベクターと呼ばれるプ ラスミドあるいはファージにつなぎ、新しいDNAを 創る。これを組換え DNAと㭔び，ホス卜菌に導入し て形質転換を行なう。この一連の技術を遗伝子工学と呼 んでいることは彫知のとおりである。ルーメン細菌遺妘 子のクローニングはは上んど大腸菌のプラスミドベク夕 一あるいはファージべクターを使用して行なわれており， 大腸菌を宿主として組換え DNA を增殖させ，解析に 使用している。そその酵索遺伝子の多くは，ルーメン細菌 自身のプロモーターが，大腸菌の RNA ポリメラーゼ により認識されて転写され，大腸菌りボンームで翻訳さ れている，しかし通性嫌気性菌である大腸菌を絶対嫌気 
条件下のルーメンに定着させ瀻維質分解に寄与させ得る こよへの伦惧があるので，ルーメン菌のホストべタター 系を新たに開発する必要む支る。

次にセルロースやへミセルロースの分解醇素遗伝子が クローニングされているルーメン菌の例をいくつか紹介 寸る。

1. Ruminococcus albus

ルーメン内での植物繊維分解に寄与する主要菌株の一 つであり，われわれを含めいくつかのチームで研究が進 内ら机ている。加机れは R. albus F-40 加ら 3 つの 異なるエンドグルカナーゼ尔，エキングルカナーゼ(3),

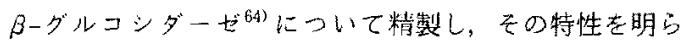
かにしている。

R. albus F-40 のエンドグルカナーゼのひとつ EGI* の䢱伝子がタローニングされ机塩基配列が決定されて いる ${ }^{67)}$. EGIをコードする遗伝子は，1，218塩基対 (bp）功なっており，これより406のアミ/酸配列が 推定されている。翻訳開始コドンの前には一35 配列と-10 配列と思われるTATACA とAATAATを含むプロ モータ一領域が存在し、リボンーム結合部位のコンセン サ又配列と予想される AAGGAGGA 配列が存在する。 さらに終止コドンの下流域にパリンドローム（回文）構 造があり mRNA ポリメラーゼのターミネーターとし て㗢くと予想される，R，albus F-40 加ら精製された 酵素のひとつは $\mathrm{N}$ 末端アミノ酸配列として, Ala-AlaAsp-Glu-Ser-Glu-Thr-Glu-Asn-Val-Pro-Val-SerGln-Thr 在保有する。この配列は44番目のアミノ酸 加ら始まっている，従って上記配列より前に存在する 43 個のアミ/酸は成熟蛋白質になる段階でシグナルペ プチドとして取り除かれると考えられる。この EGIは C. thermocellum のエンドグルカナーゼ $\mathrm{E}^{25)}$ と高い 相同性がある。しかし，C. thermocellumでは，こ の領域は活性発現領域上は考元られていないので，わず かな了ミ/酸配列の相違吕，活性発現を左右しているこ とがうかがえる。さらに EGIをコードする遣伝子 egI の一部を5’側で切り取って短縮した。これを大腸菌で 発垷させた結果, 推定されるシグナルペプチド切断部位 よりもさらに15個のアミノ酸を取り除いて短くした醉

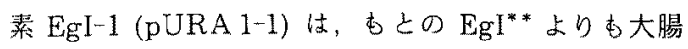
菌で高い生産性を示し，EGIに比へ至適 $\mathrm{pH}$ は酸性剆 にシフトし，熱安走性が若干劣っている。このここは，

*:R. albus F-400遭伝子 egIにより R. albus で発現している醇素。

** : R. albus F-40の遺伝子 egI 大腸菌で発現さ せて精製した醉素.
この $\mathrm{N}$ 末端側が酵素の熱安定性に寄与していることを 示惨している70). (図 1,2 )

R. albus F-40の $\beta$-グルコシダーゼ遗伝子について 屯塩基配列が決定されている68. この遗伝子は，2,841 bp からなって扔り推定されるアミ/酸配列は 947 個で ある．大腸菌で発現した醅素の $\mathrm{N}$ 末端のアミノ酸配列 は, Met-Ile-Lys-Asp-Trp-Asn-Glu-Tyr-Leu-GluLys-Ala-Ala-Glu-Val-Asn-Ala-Glu-Gly で $R$. albus F-40 から精製した酵素の $\mathrm{N}$ 米端と全く同じで あった：このこ上加ら本䤃㨞はシグナル配列をむたず， 従ってR. albus の菌体外には分泌されないことが予

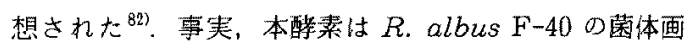
分から精製されている64).

R. albus SY 3 のエンドグルカナーゼ遺伝子 celA 亡 $\operatorname{celB}$ についても塩基配列が決定されている71)。をれ ぞれ $1,095 \mathrm{bp}, 1,227 \mathrm{bp}$ からなり, 推定される酵素 EGA 上 EGB はそれぞれ分子量 41,200，45,500 と推 定されている。 albus F-40の EgI と81\%あありほぼ同じあのであろ う之思われる。

R. albus 8 染色体の $\lambda$ ファージを使っだライブラリ 一からセルラーゼ活性を示す 10 種類の異なる制限醭素 地図をもつクローンがえられている311.このうちの3つ はエンドグルカナーゼ, 3つはエキりタイプのグルカナ 一ゼ, 残りの 4 つはエンドグルカナーゼとエキングルカ ナーゼに加え $\beta$ ーグルコシダーゼ活性をす示す複合型の クローンであることが判明している。入ファージを使っ たクローニングは一般に大きいサイズの DNA（10kbp 以上）を捙入できる、複合型のクローンには複数の酲素 遺伝子がのっている可能性があり，これら遺伝子がクラ スタ一在形成していることを示唆していて興味深い，ま たR. albus AR 67 からはエンドグルカナーゼ活性を あつ3つの翼なるクローンがえられており，AR68 か らは1つのクローンがえら机ている。しかしこれらの遭 伝子問は相同性汃低いことが明らかになっている ${ }^{91)}$.

2. Fibrobactor (Bacteroides) succinogenes

本菌もルーメンでの植物䋘維分解に関与する主要菌の ひとつであり，よく研究されている。この菌は最近にな り Fibrobactor 上再分類された ${ }^{56)}$. 本菌の織維分解で の役割, 分類, 生理については文献を参照されたい年。

從来の生化学的精製法に上って2つのエンドグルカナ 一ゼ51，七ロデキストリナーゼ 33.34 ，七ロビオシダー ゼ35〉などが単離され，その特性が報告されている。一

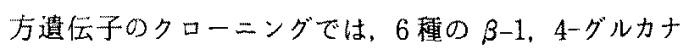
一ゼ活性をもつクローンが得られ 
AACCTTCTGCCAAAGTGGTGGACGGTGTTGAGGTATACAACAGCGGCAACTCGAAGAAGTATACAACGAGCGT GCTGAGTGGTATGCAAAGCAGTACGGTTTTCGTATGACGGCAGAGGACAATCACATCTTGATAAGCCAAGTGA AGACTTGCCGCCATTATCAGTGAGGTGAGGTTTGAATGTGCTGAGGATTATGCGGGTGCATTTITTICAGGCAGG GTAATACCGCTGTATCCGAAGGAACGGCTTTGATATACAAATGTTGTACCTGGAACATTTTGGGGTATATACATT

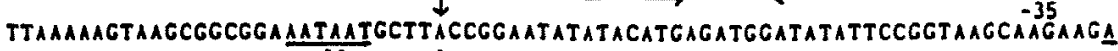
-10 ti

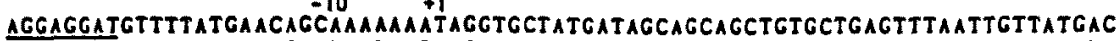

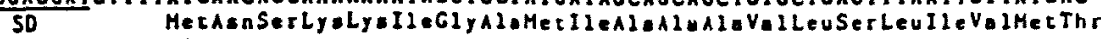

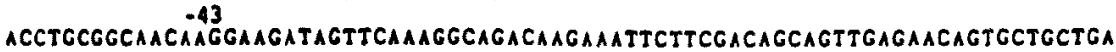

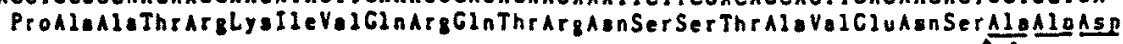
$a+1$

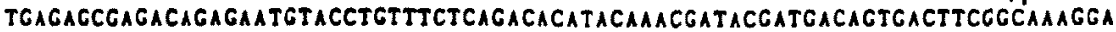

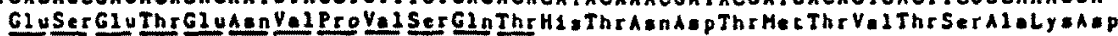
CCTGGTACCAAAGATGACCAACGGATGGAATCTCGgaAATACTATGgATCCTACAGCTCACGCTCTCGGATCGGa

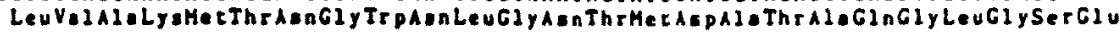
GCTTACCTCGCTTCCTTTAAAGGTTACCACAAACAAGTACATGATAGATATGCTGCCCGAACCACGATTCAATGT

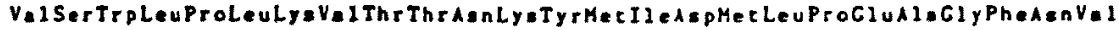

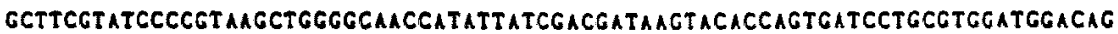

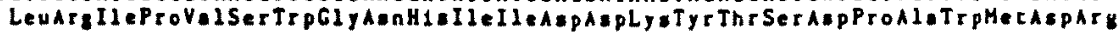

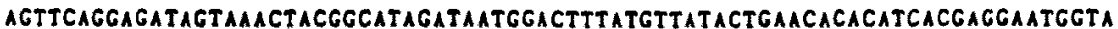

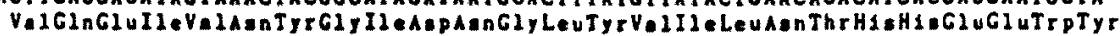

TATGCCCAAGCCCAGCGAGAaGgaCGGCGATATTGAGGaGaTCAAAGCTGTaTGgGCACAGATAGCCGACCGTTT

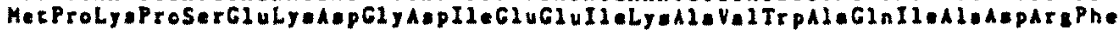

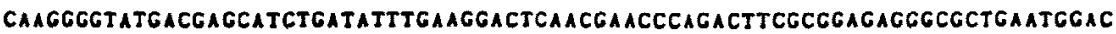

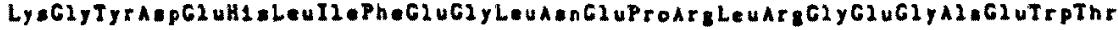

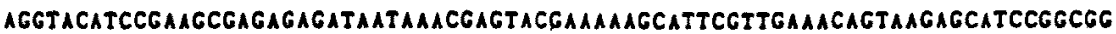

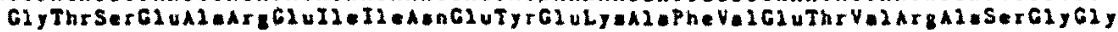

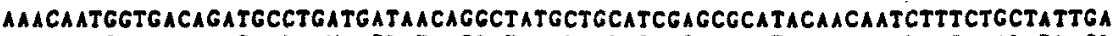

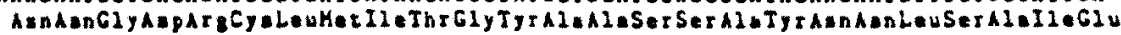

ACTTCCCCAGGACAGTGACAACCTCATAATCTCGCTACACGCATACCTGCCTTACTCATtTCCACTGgataCAAA 1273

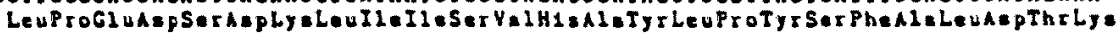

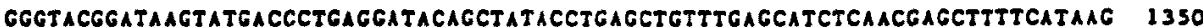

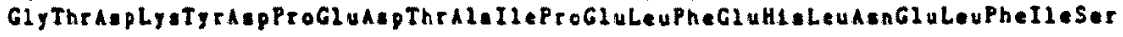

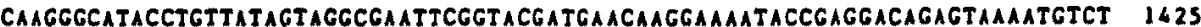

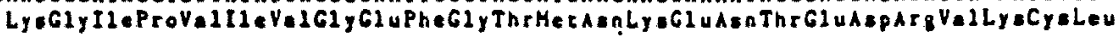

GCAGGATTACCTTCCACCTGCGCCAAATACGATATACCCTCTGTATCGTGGGATAACTATGCACCCATCGCTAA 1500

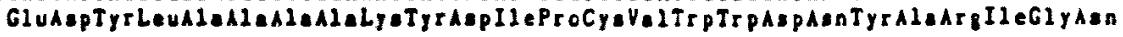

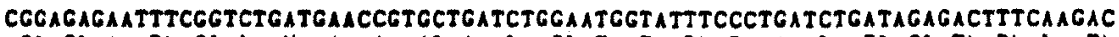

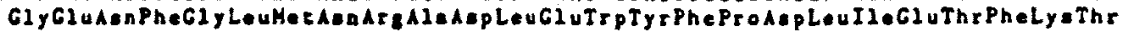

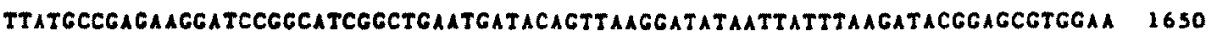

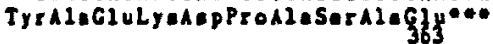

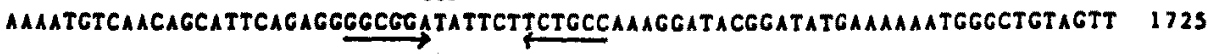

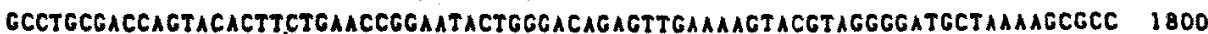
TATGATCTTATCCTGCCCGAGGTATACCTGCAACACCCGGGAGTAGATTACCGCATAGACAACATACACCGCACA 1 B7S ATGAATGATATATIGAAAAGgTGTATTTGAGA TACAAGGTGCTATGATATATATCGAGAGAGTGCAGTCC 1950 CACGCCACAGTGACACCACGTCTTATCGGCGGGATAGACCTGGACCAGTACGAATACTACAAAGGCTCCCAATCT 2025

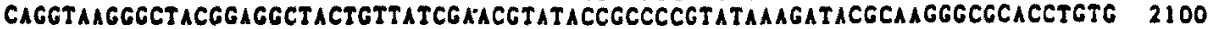

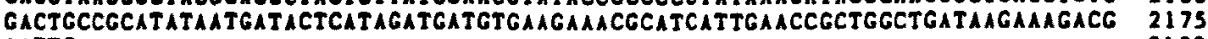
AATC

2180

Fig. 1. Nucleotide and amino acid sequence of the $R$. ablus endo-1, 4- $\beta$-glucanase gene. The underlined sequences marked -35 and -10 refer to RNA polymerase recognition and binding sites, respectively. SD indicates a possible rebosome binding site. The initiation site for the transciription is indicated by a vertical arrow. The cleavage site of the signal sequence is shown by an arrowhead. Palindromic sequences in the $5^{\prime}$ and $3^{\prime}$ flanking regions are denoted by horizontal arrows. The stop codon is indicated by three asterisks. 


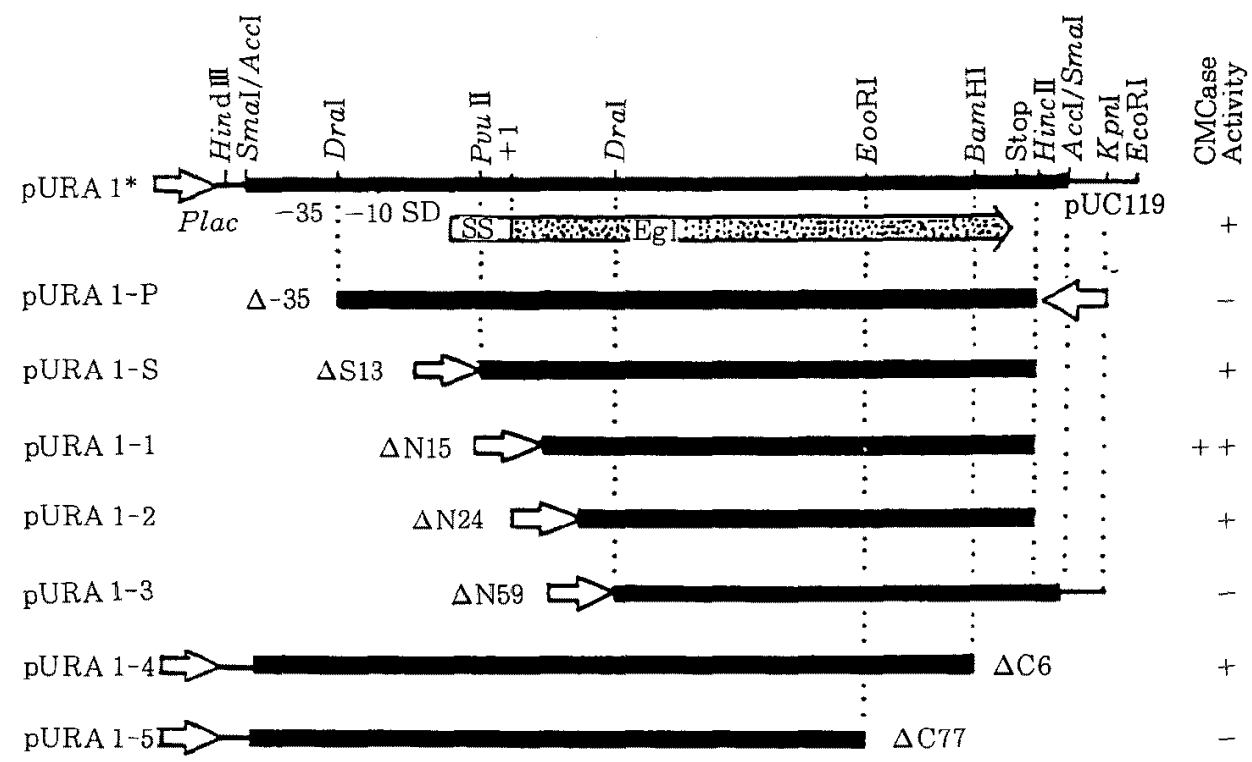

Fig. 2. Restriction map showing the construction of the $R$. albus CMC-degrading enzyme gene starting with progressive $\mathrm{N}$-terminal deletions and then the $\mathrm{C}$-terminal deletions. Abbreviations : Plac (arrowhead), promotor of lactase in pUC vector; $-35,-35$ region; $-10,-10$ region; SD, a possible ribosome binding site; SS, signal sequence.

かにされている。この他にキシラナーゼ32.79), セロデキ ストリナーゼ239などの遗伝子がクローニングされてい る、いずれの遗伀子む F. succinogenes のプロモー夕 一により発現し SD 配列なども大腸菌において正常に 機能している.

F、succinogenes S 85 の cel-3 遺伝子はエンドグル カナーゼ活性とセロビオシダーセ活性の両方を有してい る酵素蛋白質 EG 3 をコードしている ${ }^{53)}$.この頲伝子は 1,974 bp の読枠をむちアミ/酸配列加ら推定した分子 量は 73,400 であるが，大腸菌からのそれは $43,000^{83)}$ と かなり小さいことから，大腸菌内で翻訳後プロテアーゼ によって分解されたことがうかがえる。この大晹菌で発 現した蛋白質 EG 3 を抗原とし抗体を作成してウェス タンブロット法で確認すると，F. succinogenes が産 生する粗醉菜試料中では 118,000 の分子量を持つ蛋白質 として存在していることが判明した，したがって遗伝子 から推定した分子量 73,400との差は, 栯加付加されて いるか，あるいは膜成分上会合していることなどに起因 すると考えられている.この cel-3 は C. thermocellum の celC $C^{75)}$ と高い相同性がある.F. succinogenes S 85 のエンドグルカナーゼ EG 1 と EG 2 はカラムクロ
マトグラフィーにより精製されておうらい，それぞれの抗 体を使った武験では，結晶性セルロースを炭素源とした ときに EG 1 は早い培養時期から培地中に遊離される ことが判明している. EG 2 細胞に結合しており， EG 3 は培地と細胞結合の両画分に見いだされている ${ }^{54}$. また EG 2 はトリプシン消化により分子量 43,000 と 51,000のペプチドに分かれ，43,000のぺプチドは結晶 性セルロースに結合する。一方51,000のペプチドは元 の $\mathrm{EG} 2$ 上同梯な $\mathrm{CMC}$ に対する活性を有しているす のの, 結晶性セルロースに対してはその活性が半分に减 ってしまう。このことからそれぞれのぺプ手ドは基質結 合ドメイン上醅素触媒ドメインを形成しているあのと考 えられている52). EG 3 はまた CMC に対する活性のみ ならず $p$ ニトロフ ニル- $\beta$-D-セロビオシドや $p=$ トロフェニルー $\beta-\mathrm{D}-$ ラクトシドにあ活性を示す ${ }^{53)}$.この

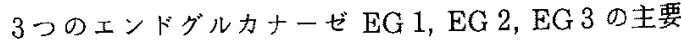
な基質分解物はそれぞれセロどオース，セロテトラオー ス，セロトリオースであり，セルロースあるいはグルコ 一スを炭素源とした培養では $3 つ$ 醉菜はいずれす生合 成されるが，セロビオースの場合には EG 1 の生成の みが归制されることが明らかになっている 
F. succinogenes S 85 のセロデキストリナーゼ尷伀 子もクローニングされている232. このセロデキストリナ 一ゼはセロオリゴ糖に対して活性を有しているが CMC は伃解しない，大腸菌で発現した醉素之，元菌の菌体外 培養滤液より精製したセロデキストリナーゼとでは同じ ものが得られている．この遭伝子は大腸囷内でグルコー スによるカタボライト㧕制をうけ，セロビオースにより 誘導されない。

キシラナーゼ䅞伝子もタローニングされ，F.succinogenes S 85 の培養濾液より精製されたキシラナー ゼと同じ $\mathrm{Km}$ 值をすつ醉素が大腸菌で発現し、その 46 \%がペリプラズムに存在している ${ }^{79}$. この遗伝子は大 腸菌内でカ夕ボライト抑制を受けずキシランやキシロー スにより誘導されない．F. succinogenes 135 からもキ シラナーゼ遗伝子がクローニングされている323.この遺 伝子はS85の6の上は相同性がなく，大腸菌で発現し

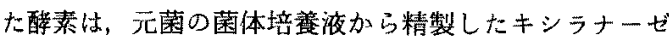
とは異なっており，むしろ高い活性を示している。

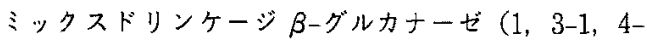
$\beta$-D-Glucan 4-Glucanohydrolase) は，リケナン

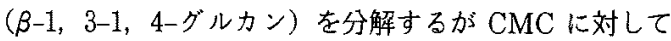
は活性を示さない酵素で，これあクローニングされてい る ${ }^{36)}$.これまでに知られている多くのグルカナーゼがリ ケナンをよく分解するためにリケナンだけを分解する本 酸素は檢出されていなかったが，クローニングに上りを の存在がはじめて明らかになった，本酵素遺伝子の塩基 配列では ${ }^{86)}$, 前述の celC や他のグルカナーゼとの相同 性は低いが, Bacillus subtilis のリケナーゼ60) と高い 相同性を示している．また特徴あるアミ，酸配列も見つ かっている，これは C 末端側に存在するセリンの多い 領域で, Pro-Xxx-Ser-Ser-Ser-Ser-(Ala or Val) という配列が 5 回屯繰り返し連なっている構造である. この配列はコンピュータによる予想ではターン・アルフ アヘリックス・ターン構造をもっており，おおまかにい って基質の繰り返し構造と大きさがあうので，酵素と基 質との相互作用に何らかの働きを屯つであろう。しかし この部分を削った酵素であ活性は極端に落ちないことか らこの配列が全体のコンフォメーションや活性中心に対 する貢献は少なく，むしろ醉素-基質複合体の安定化に 働く領域と著者らは考えている ${ }^{86)}$. 同じルーメン細菌で ある Butyrivibrio fibrisolvens H $17 \mathrm{c}$ のンドグル カナーゼにおいてす Pro-Asp-Pro-Thr-Pro-Val-Asp といった繰り返しが報告されている゙．しかしここのよ うな繰り返し配列は他の微生物のグルカナーゼ20)にお いても一般に見られるもので，最近ではこういったプロ
リンを含し繰り这し配列はリンカー配列と呼ばれ，酵素 の触媒部位とセルロースへの結合部位とをつなぐヒンジ の部分に其通な配列として認められるようになってきて いる ${ }^{22)}$ （図 3)

F. succinogenes AR 1 のエンドグルカナーゼ遺伭 子 end $A_{\mathrm{FS}}$ は，ニニークな塩基配列を有している この遗伝子は開始コドンから $379 \mathrm{bp}$, アミノ酸にして 127 番目にストップコドンが出てしまう。しかし一塩基

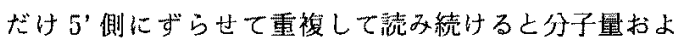
び途中のアミノ酸配列寻夹際に精製されている醉素のそ れらと一致する．すなわちコードされている2つの読み 枠（ORF1と 2）が1塩基重複して読まれることで脣 い読み枠となり，一つのエンドグルカナーゼを産生して いることになる.このようなフレームシフトの原因のひ とつとしては, ORF1 の終止コドンの前にある Arg と 4 つの Thr に使用頻度の少ないコドン AGG と ACA がそれぞれ使用されているためと考えられている．使用 頻度の少ないコドンのアミノ酸を転移できる tRNAは その含量も少ないため, 連続使用によって tRNAの枯 渴が生じる、これを補うためには，使用頻度の高いコド ンを使用することになり，従ってフレームシフトを起こ すはうが都合がよい ${ }^{93}$. 一力，16 S rRNA と結合する AGCGGG のような SD 配列でフレームシフトが起き ることも報告されている ${ }^{94)}$. end $A_{\text {FS }}$ の ORF 1 の終止 コドンの前には AAGGAAGというSD 配列と推定 できるものす存在しているので, このこともフレームシ フトの一因になっているであるう.（図 4)

\section{Ruminococcus flavefaciens}

ルーメンでの植物緎維分解に関与する主要菌種のひと つであるが，上部の $R$. albus や F. succinogenesに 比べ報告はすくない.

R. flavefaciens FD-1 のクローニングされたェンド グルカナーゼは，大腸菌ではグルコースによるカタボラ イト掫制を受ないため大量に発現生産され，その大部分 は大腸菌のペリプラズムに蓄積されている゙2。また同じ 株のセロデキストリナーゼ遺伝子の塩基配列が決定され ている ${ }^{90)}$. この遺伝子 (celA) は $1,056 \mathrm{bp}$ で，アミ， 酸 352 個からなっている．酵素は大晹菌のペリブラズム に蓄積するが，アミノ酸配列上にシグナルに相当する部 分が無いので，異なる機構により分必されると推定され ている。

R. flavefaciens 17 の $\lambda$ EMBL 3 のライブラリー办 らは 4 つの異なるキシラナーゼがクローニングされてい る18). そのうちのひとつのクローンはキシラナーゼ活性 の他にキシロシダーゼ活性と $\beta(1,3-1 ， 4)$ グルカナ 
800

820

840

860

880

C GAK CCT GCT CCG CAA TCT TCT AGC AGC GCT CCG GCA TCT TCT AGC AGT OTT CCG GCA AGC TCC TCT AGC GTC CCT GCC TCC TCG AGC AGC Glu Pro Ala Pro Gln Ser Ser Ser Ser lla Pro dla Ser Ser Ser Ser Val Pro Ala Ser Ser Ser Ser Pal Pro Ala Ser Ser Ser Ser 270 280 290

900 920

GCA TTT GTT CCG CCG AGC TCC TCG AGC GCC ACA AAC GCA ATC

Ala Phe Tal Pro Pro Ser Ser Ser Ser Ala Thr Asn Ala Ilu

Mixed-]inkage $\beta$-glucanase gene of $\underline{F}$. succinogenes $\$ 85$

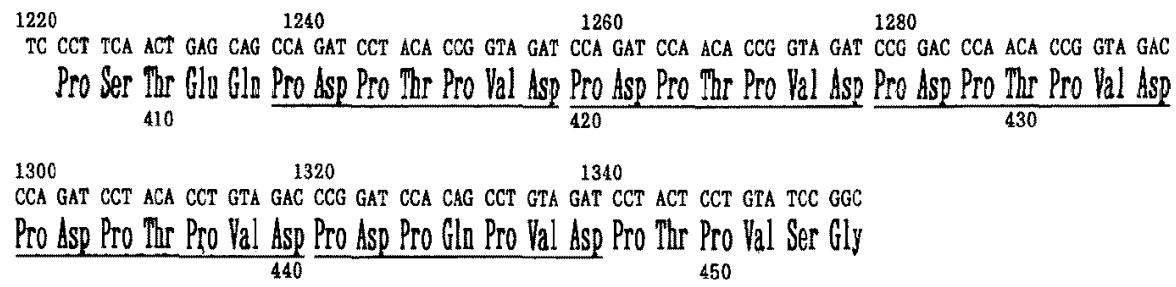

Endoglucanase gene of B.fibrisolvens $\mathrm{H1} / \mathrm{c}$

Fig. 3. Partial nucleotide sequencies of the direct repeats from Fibrobacter succinogenes ${ }^{86)}$ and Butyrivibrio fibrisolvens. ${ }^{4)}$

Repeat sequences are underlined.

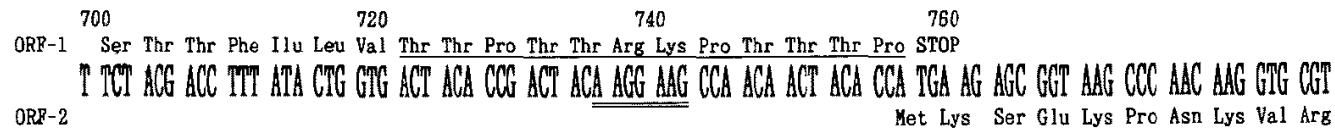

Fig. 4. Nucleotide sequence of a putative frame-shift region of endoglucanase gene of $F$. succinogenes AR $1 .^{\text {B) }}$

A proline and threonine-rich region of $O \mathrm{RF}^{-1}$ is underlined.

Potential Shine-Dalgarno sequence for ORF-2 is double underlined.

一や活性をむ発現している.

4. その他

(1) Prevotella (Bacteroides) ruminicola

この菌種も雪分類が行なわれ Prevotella 属が提案さ れている ${ }^{76)}$. Bacteroides ruminicolaはセロビオー スをはじめ低分子のセルロース分解物（セロデキストリ

ン）を利用できるあのの，ボールミルセルロースなどの 高尔子七ルロースを炭素源としては生育できない菌種で ある。

B. ruminicola AR 20 からエンドグルカナ一ゼ遗伝 子がクローニングされている ${ }^{100)}$ ，この遺伝子により大 腸菌でつくられたエンドグルカナーゼはキシランにも活 性を示しており，デレーションによる变異では，この2 つの活性が同一遺伝子上にあることが示されている。
B. ruminicola $\mathrm{B}_{1} 4$ のエンドグルカナーゼもクロー ニングされ ${ }^{48)}$ ，程基配列が決定されている49).この菌の 遗伝子の場合にあ上述のように，はじめの ORF は比 較的短く，すぐにストップコドンがあらわれる.しかし 大腸菌で生産されるェンドグルカナーゼ出分子量 40,500 である，その上この蛋白質の抗体で B. ruminicola $\mathrm{B}_{1}$ 40 培篒上清を調べるとさらに大きな 88,000 と 82,000 の蛋白質が存在し，これら二つの蛋白質の $\mathrm{N}$ 末端のア ミノ酸配列はそれぞれ初めの ORF と二番目の ORF に存在していた。これら分子量の異なる3つの酵素が同 一の遺伝子にコードされており，CMC やキシランに対 しても同程度の活性を示すこと，さらに40,500の蛋白 質に対する抗体が 88,000 と 82,000 の蛋白質亡強く反応

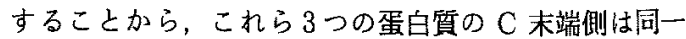


であるうと推定されている

B. ruminicola 23 のキシナーーゼ遮伀子もクローニ ングされている ${ }^{95}$.このキシラナ一ゼ遭伝子は, Bacteroides のシャトルベタターを用いて，ルーメン 細菌ではないBacteriodes fragilis ${ }^{96)}$, B. uniformis $^{96)}$, B. thetaiotaomicron ${ }^{97)}$ で発現している. B. thetaiotaomicronでは，この遠伝子がさらに染色体上に移さ れ，安定なキシラナーゼ活性を発現している ${ }^{97)}$.一方 B. ruminicola D $31 \mathrm{~d}$ のキシラナーゼ邀伀子如クロ ニングされている ${ }^{98)}$. しかしこの遺伝子はサザンハイブ リダイゼーション法での比較では B. ruminicola 23 のキシラナーゼ遗伝子とは全く異なる塩基配列を有して いることが明らかとなっている。

(2) Butyrivibrio fibrisolvens

ルーメン中でキシランの分解に関与している $B$. fibrisolvens GS 113 のキシロシダーゼ遺伀子はクロー ニングされ77)，塩基配列を決定され ${ }^{899} ， 1,551 \mathrm{bp}, \quad$ アミ ノ酸 517 個より構成されていることが明らかとなってい る.大腸菌で生産された本遺伝子の酵素は， $\beta$-D-キシ

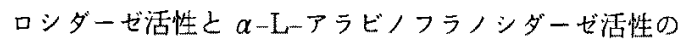
二つの機能をもっている．またこの遺伝子には自身のプ ロモーターが含ま机ていないために pUC 18 の lac プ ロモーターの下流に組み込んだ時のみ活性を示すことと, ターミネーターが無く, すぐ下流に SD 配列と次の ORF が存在する事実から、この遺伝子はある種のオペロンの 一部分だと予想されているが年，その全体の特性はまだ 不明である。

B. fibrisolvens 49 の産生する二つのキシラナーゼの
うちのひとつがクローニングされ，塩基配列が决好られ ており，推定されるアミ，酸 411 個で構成されている45). この醉菜はセルラーゼ，アラビノシダーゼ，およびキシ ロシダーゼ活性を亦さないエンド型キシラナーゼである ことが明らかにされている。

B. fibrisolvens $\mathrm{H} 17$ c のセロデキストリナーゼ遺伝 子がクローニングされ塩基配列が決定されている5. 本 遺伝子（ced 1）は， 1,641 bp，アミノ酸 547 個からな っており，C. thermocellum のエンドグルカナーゼ $\mathrm{D}^{33)}$ 上相同性があることが明らかになっている。この 株のエンドグルカナーゼについてすクローニングされ塩 基配列が決定されている4. エンドグルカナーゼ end 1

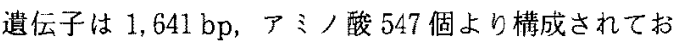
り，大腸菌で生産された本遗伝子の醇素蛙， $\mathrm{CMC}$ のみ ならずキシシンに対してい活性を有している。一種類の 酵素蛋白質が 2 つ活性を発現できるためには，活性部 位がどの上うな構造になっており，どのような作用機作 で発現するかといった点は與味ある問題として残されて いる.

また B. fibrisolvens A 46 のエンドグルカナ一セ遗 伝子（celA）は，1,296 bpでアミノ酸 432 個からなっ

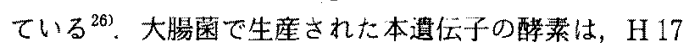
cのエンドグルカナーゼと同様な基質特異性を示したに あかかわらず構造的には㥵同性を持たないこ上が明らか にされている。

以上のようにルーメン菌が産生する植物繊維分解系の 多くの酵素がクローニングされており，それらのうち塩 基配列の決定されているものについては垡2にましめた。

Table 2. The sequenced genes encoding $\beta$-glycan-degrading enzymes from rumen bacteria

\begin{tabular}{|c|c|c|c|}
\hline Bacterium & Gene (bp) & Enzyme & References \\
\hline Rumincoccus albus F-40 & egI $\quad(1,218)$ & Endoglucanase & 67 \\
\hline R. albus $\mathrm{F}-40$ & $\operatorname{bg} 11 \quad(2,841)$ & $\not \partial$-Glucosidase & 82 \\
\hline R. albus SY3 & $\operatorname{ce} 1 A(1,095)$ & Endoglucanase & 31 \\
\hline R. albus SY3 & $\operatorname{celB}(1,227)$ & Endoglucanase & 71 \\
\hline R. flavefaciens FD-1 & $\operatorname{cel} A(1,056)$ & Cellodextrinase & 90 \\
\hline Fibrobacter succinogenes S85 & ce13 $(1,974)$ & Endoglucanase & 53 \\
\hline F. succinogenes $\mathrm{S} 85$ & $(1,047)$ & Licheriase & 86 \\
\hline F. succinogenes AR-1 & endAFs & Endoglucanase & 8 \\
\hline Bacteroides ruminicola $\mathrm{B} 14$ & & Endoglucanase & 49 \\
\hline Butyrivibrio fibrisolvens 49 & $x y n A(I, 233)$ & Xylanase & 45 \\
\hline B. fibrisolvens GS113 & $x y 1 B(1,551)$ & Xylosidase & 89 \\
\hline B. fibrisolvens $\mathrm{H} 17 \mathrm{c}$ & endl $(1,641)$ & Endoglucanse & 4 \\
\hline B. fibrisolvens $\mathrm{H} 17 \mathrm{c}$ & $\operatorname{ced} 1 \quad(1,641)$ & Cellodextrinase & 5 \\
\hline B. fibrisolvens A46 & $\operatorname{cel} A(1,296)$ & Endoglucanse & 26 \\
\hline
\end{tabular}


各種の遮伀子が大腸菌で発現されているが，クローニン グ手法の特性から，大腸菌で発現しやすいが実際には元 菌で発現していない酳素遗伝子のみを採っている可能性 ああること忘れてはならない，事奏われわれが使用し ているR. albus の場合でも，その培養上清に遊離さ れてくるメジャーな酵萃をコードしている遀伝子は，大 腸菌を用いるクローニング法では未だに単離できていな い.クローニングされてくるのは元囷での発現量の少な いいわゆる代替用の半休眠䢙伝子か子しれない、いいか えれば大腸菌内で働きうるプロモーターの下流にある椣

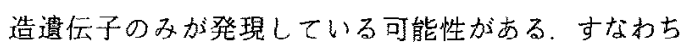
R. albus で常時発現している息伝子はむしろ大腸菌と いう異種菌体では発現しにくいような何らかの機構をも っているのであろう。したがって大腸菌以外の宿主を用 いれば，別の遗伝子をクローニングできる可能性もある。 例えば R. albus はグラム陽性菌であるので，グラム 陰性の大腸菌よりも枯草菌やStreptococcusといった グラム陽性菌を宿主としてクローニングを試みること屯 必要之思われる。

実際に量伝子が元菌で発現しているか否かは，大腸菌 で産生した酵素に対して作成した莯体を用いた免疫反応 で容易に識別できる、この試験によれば元菌で発現して いる酵素の分子量に比べ大腸菌で生産した酔菜のそれは 小さい場合が多い，これは大腸菌内で生成された異種遺 位子産物が翼種蛋白質として誑識された結果，大腸菌プ ロテアーゼにより蛋白澌分解を受けたと予想される。こ の他の理由としては元菌で産生された酵素蛋白質がグリ コシデーションなどの修飾をうけているのに大腸菌では 全くないためである，こういった遺伝子レベルの知識を 増やすことが、ルーメン細菌の改良に重要であると考え ている。さらにクローニングされた遺伝子は in vitro での变異遣伝子の作成が可能であるため，上り活性の強

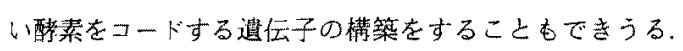
そうすれば次のステップとしては，この構築遺伝子を元 の親株にもどし安定に発現させる方法が必要になる，

\section{ルーメン細菌への遣伝子の導入}

ルーメン細菌のセルロース分解機能の改鼠にかかわる 遗妘子の導入は，現在のところ大腸菌や枯草菌を用いる 基本的手法で試みられている，をの概略を以下に述べる。

1.プラスミドを利用する力法

プラスミドを遺伝子の運び屋（ベクター）として利用 する今法は大腸菌で最も進んでおり，利用し易い特徽を 持った種々のブラスミドが棈築され市販されているプ ラスミドはそれ自身に複製領域を持っているので，ホス
卜八安定に㓦入さえできればプラスミドに組み込きれた 遭伝子は発現し形質転換しやすい，しかしプラスミドの 複製機構の違いから大腸菌のプラスミドをそのままルー メン細菌の形転换には利用できない、したがって、ル ーメン細菌の形質転換にはルーメン細菌のプラスミドを ベクターとして使用することが望ましく，このためルー メン細菌の保有するプラスミドの検索が行なわれている。 すでにルーメン細菌からいくつかの小型プラスミドが発 見され単離ざれているが，いずれも形䓄が不明ないわゆ る「クリプティク」プラスミドである. R. albus 06 株よよび R. Alavefaciens の 2 秼より各 1 種類のプラ スミドが分離されている゙，そのいずれむがクリブティ クである。このうちのR. flavefaciens 加ら得られた pRA 186 は $5.2 \mathrm{kbp}$ の大きさでベクターとして利用で きる可能性在持っている。またR. albus F-40 は 15.3 2 $7 \mathrm{kbp}$ の大さの 2 種類のプラスミドをもって いる ${ }^{69} .7 \mathrm{kbp} の$ pRAB は Bam HI, Pst 1 により 1 力所のみの切断サイトを保持しているのでベクターとし て利用できる可能性をもっている，Selenomonas

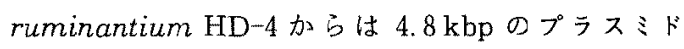
が47, またS. ruminantium の分離菌株からは 6 種 類のプラスミドが単離されている61?. Butyrivibrio fibrisolvens からは非常に大きなプラスミド84) と2.7 $\mathrm{kbp} の \mathrm{pOM} 1^{44)}$ が分離されている. pOM 1 からは種々 の大腸菌レプリコンとの組合せによりマーカーとして抗 生物質耐性をむったベクターが構築されているが，䅐株 の形質転換は難しいようである。こういったプラスミド の複製領域のみを取り出し大腸菌で利用できるプラスミ トにつなぐことによる，シャトルベクターの開発が現在 進められている基本的な戦略であろうが、まだ其体的な 進展はみられていない，最近になり in vitroで作成し たプラスミドをホスト菌に導入するための手段として, 電気穿孔法（エレクトロポレーション）の研究が進的ら れている ${ }^{14,43)}$ 、ルーメン細菌には抗生物質耐性を有する あのが見つかっており，これらの遗伝子をマーカーとし て利用できる可能性がある.17)。

\section{2. ファージを利用する方法}

ルーメン細菌に感染するファージの存在については報

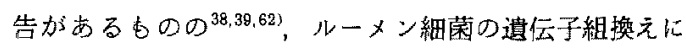
有用なファージは，現在まだ発見されていない，

3. 接合伝達を利用する方法

プラスミドの接合任達はその分子サイズが比較的大き な゙場合に起きる現象で，そのプラスミド保有株を，おっ ていない秼と接合させることによりプラスミドを伝達さ せる方法である。 
Bacteroides ruminicola 233/M 2/7 は多数のプラ スミドをもつテトラサイクリン耐性株である．この怢の テトラサイクリン耐性遗伝子をもつ $19.5 \mathrm{kbp}$ のプラス ミト pRRI 4 を接合伀達 ${ }^{17}$ およびエレクトロポレーシ ョン ${ }^{88)}$ の両方法により B. ruminicola 形質転換しテ トラサイクリン耐性を付与することに成功しているので， このプラスミドをべクターとして利用できる可能性がで てきている．しかし大腸菌で複製しないことと若干分子 量が大きい点でべクターとしては難点がある.

腸内細菌 Bacteroides uniformis のプラスミド pRDB 5 はルーメン細菌 Prevotella ruminicola $\mathrm{B}_{1} 4$ に接合伝達されている ${ }^{78}$.このプラスミドは大腸菌のべ クター pBR $328 の 一$ 部, 腸内細菌 Bacteroides 属の クリプティクプラスミド $\mathrm{pB} 8-51$ とテトラサイクリン 而性遭伝子より構築されており，大腸菌においても複製 できる。しかしなぜか pBDB５はエレクトロポレーシ ヨンでは形質䎐換できないが，大腸菌からプラスミド R751による可動化により B. uniformis へ移すこと に成功している．B. uniformis 加らP. ruminicola へは，染色体上の可動要素により可動する．従って大腸 菌功ルーメン細菌へ遺伝子を直接移動させることはで きないか，腸内細菌 B. uniformis を経由して大腸菌 よりルーメン細菌へ遭伝子を移動できる。

Butyrivibrio fibrisolvens $k$ Enterococcus faecalis から接合伝達により pAM $\beta 1$ とトランスポゾン Tn.916が移されている30?

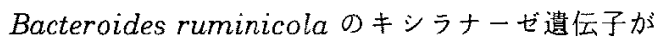
晹内細菌 B. thetaiotaomicron の染色体上に移され発 現に成功している ${ }^{97}$. 大腸菌で組換えた遺伝子を R 751 を使用して B. thetaiotaomicron に導入したプラスミ $\vdash \mathrm{pBTX} 1$ (大腸菌発現ベクター pUC 18 にキンラナ 一ゼ遗伝子を組み込んだもので Bacteroides 内で複製 できるレプリコンを持っていない）が，菌体内で相同組 換えにより染色体に組み込まれたものである。また同様 に導入された複製領域をもつ pVAL-RXのキシラナ 一ゼ活性は，約 60 世代後ではプラスミドを活とんど落 とし失活してしまったが，染色体に取り込んだほうは， 安定に保持されることが示されている。

\section{ルーメン細菌の植物臓倠への吸着と分解}

ルーメンに取り込まれた植物紻維が分解可溶化される 過程においては，まずルーメン細菌が織維に吸着する必 要があることはこれまでの電子顕微鏡観察 ${ }^{62)} ゙$ て明示 されている，したがって植物瀻維の分解効率の向上を考 える時，これまで述べてきたルーメン細菌のセルロース
分解醉菜の生産能力を増幅することの他にルーメン細菌 の繊維への吸着能力を高めるための破究をも進める必要 がある，すなわち基質である植物縹維へのルーメン細菌 の吸着能力を支配する因子を明確にし，特性を明らかに する必要がある。これまでの研究で吸着現象については 電子顕微鏡による観察結果に加え，最近いくつの生化学 的な情報が得られている，しかし吸着に関する因子の遗 伝子のクローニングなど遗伝子レベルでの研究は今の之 ころ全くないので，今後こういった方面での研究に資す るためにこれまでに報告されているルーメン菌の繊維 への吸着特性に関するデー夕を以下に紹介する

エンドグルカナーゼを生産しているにるかかわらずセ ルロース資化能が低いR. albusの菌株は，セルロー スへの吸着能が少ないことが示されていることから，吸 着上セルロース分解能とは窑接に関連していることは容 易に理解できる ${ }^{67 ?}$ ．R．albus をセルロースを土炭菜源 とする培地で連続培養するとさに，3フェニルプロパン 酸の添加に上って R. albus のセルロース分解が明ら 加に促進されることが示されている599. このとき $R$.

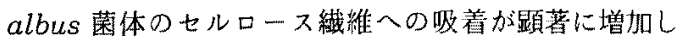
ていることが観察されている：具体的には R. albusの セルロースへの吸着能は $\mathrm{pH} 5.5$ 加ら 8 まであまり变化 はないが，5以下で著しく低下する一方，メチルセル口 一スや CMC などの基質類似体やある種の高分子リグ ニン化合物によって強く阻害されることす報告されてい る ${ }^{88)}$ ．ちなみにクマリン酸などリグニン由来のフェノー ル系化合物はB. ruminicola の生育孝阻害し，B. succinogenes の $\beta$ グルコシダーゼを強く阻害する゙6).

メチルセルロースは菌体のセルロースへの吸着を阻害 し5，一度吸着した菌体を遊離させる作用を有している。 これを利用して一度菌体をセルロース一吸着させた後, 遊離させたあとを電子顕微鏡で観察すると F. succinogenesでは規則的な笳状の溝がセルロース紻維上に残 存しているが，R. flavefaciens ではそのような溝は検 出されていない。このことは菌種によって吸着の状態や 䤉素分解の様式に違いがあることを示唆しているす0). （図 5）大麦わらへの吸着の程度も調べられている，F． succinogenes とR. flavefaciens それぞれの最大吸着 菌体量を求め，次いで両者の混合菌液に大麦加らをた し充分吸着させたところ，両菌株と屯単独の場合で得ら れた菌体量之ほぼ同じ吸着量が得られていることから， これら 2 種のルーメン菌のわらへの吸着には，それぞれ の菌株の異なる吸着領域が㗢いているすのと考えられ $3^{6)}$.

R. flavefaciens FD 1 のセルロースへの付着はホル 


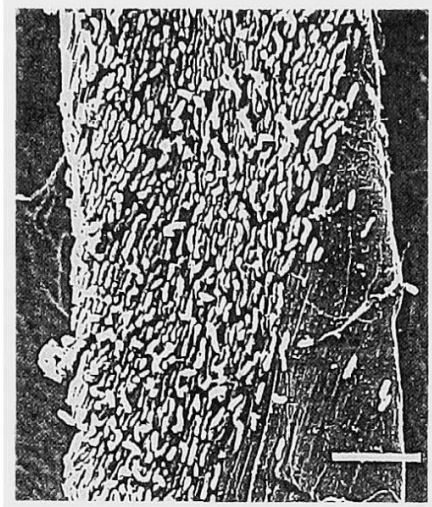

(A)

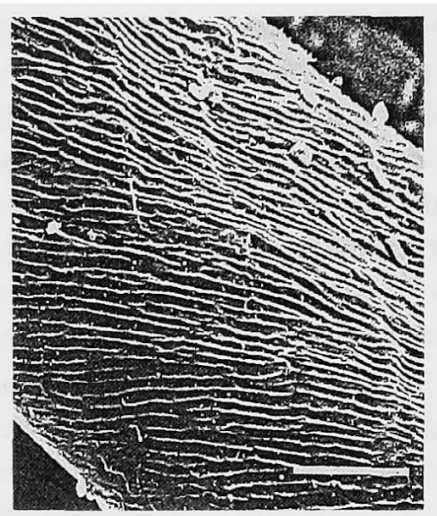

(B)

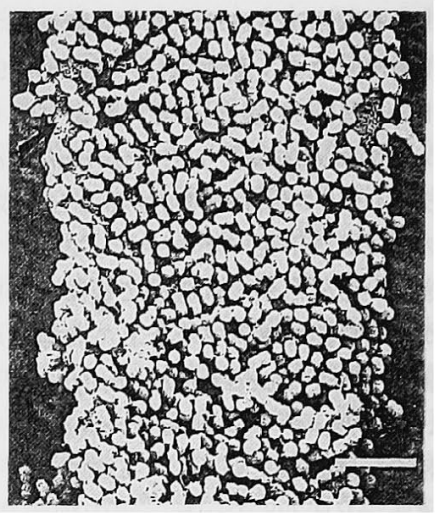

(C)

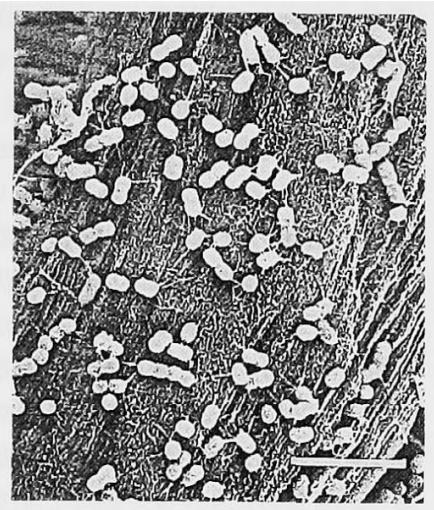

(D)

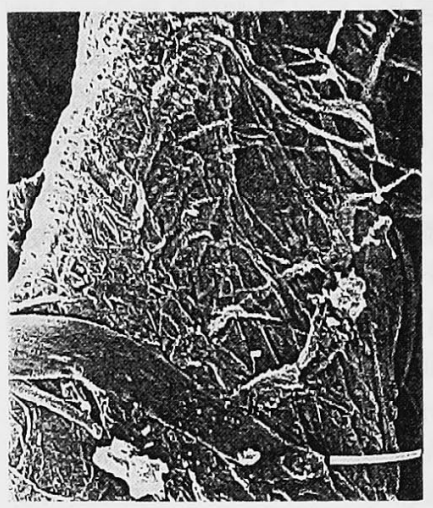

( E)

Fig. 5. SEM of Whatman no. 1 filter paper incubated with cellulolytic bacteria. ${ }^{40)}$ Adherence (A) and detachment (B) of Bacteroides succinogenes. Adherence (C) and detachment (D) of Ruminococcus flavefaciens. Control (E).

ムアルデヒド，メチルセルロース，CMC により阻害さ れる ${ }^{72)}$. また F. succinogenes S 85 の結晶性セルロー スへの付着は, 熱処理, グルタルアルデヒド, トリプシ ン，プロナーゼにより阻害される ${ }^{24)}$. また結晶性セルロ

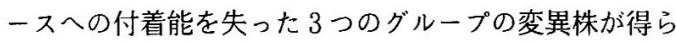
れている.これらの変異株はエンドグルカナーゼやセロ ビオシダーゼなどの酵素活性に変化はないが，クラス 1 変異株はグルコース, セロビオース, アモルファスセル ロース及び結晶性セルロースで生育できるのに対し，一 方クラス 2 ではセロビオースと結晶性セルロースで生育 できず, クラス 3 ではグルコースとセロビオースでしか 生育できないなどの差異が生じている.このことは結晶 性セルロースへの吸着にある種の特異的な蛋白質が関与
していることを示している24).

C. thermocellum で知られているセルロース複合体

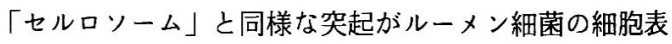
層に見つかっており ${ }^{411}$ ，これら突起物に含まれるある種 の蛋白質がセルロースへの菌体の吸着を司どっていると 考えられている．この考えにもとづいて，パスッール研 究所の Beguin一派は，これらの吸着に関与する蛋白 質遺伝子の C. thermocellum からのクローニングに 成功し, 塩基配列の決定を急いでいるとの私信を得てい る. 今後この種の何究が進むに従って，ルーメン菌の㵶 維質への吸着のメカニズムが解明されれば，難分解性の 植物繊維の可溶化を遗伝子操作技術でさらに促進するこ とになるであろう. 


\section{植物繊維分解ルーメン細菌における遣伝子工学}

\section{おわりに}

はじめにもふれたように、ルーメン細菌の遺伝子レベ ルでの研究は始まったとこるであるが，その進展にはめ ざましいすのがある。この種の研究で得られる成果は， ルーメンでの植物㵶維の分解効率を上げるにとどまらず， その応用籍囲は広くルーメン内での様々な現象の解明に 利用できると思われる、ルーメン細菌のセルラーゼやキ シラナーセ関連の諸酵菜遺伝子，あるいは植物䋐維への 吸着に関わっている蛋白質の遗伝子学入し，植物瀻維 分解能を著しく高めたルーメン細菌を遺伝子工学の技術 で新たに育種することがわれわれに課された当面の大き な問題である，目的にかなったルーメン細菌を育種する ことに成功したあかつきにはこれら組換え菌が「微生物 のるつぼ」とも言えるルーメンの中で，先住の原生動物 を始めとするばう大な種類の微生物群と共存し主要な菌 叢となりうるか否かが，次に解決しなりればならない問 題である，ついで組換え菌が反すう動物の生育にいかな る影響をもたらすかも問題となるう。このような各種の 難関克克服することにより，太陽エネルギーを豐富に蓄 積している植物織維の利用効率を高文，高級な食料の增 産が可能になるであろう。このためには畜産学の幅広い 行野の研究者との其同研究を必要亡する.

ルーメン細菌の遺伝子の組換えに関する研究は，アメ リカ, カナダ, イギリス, 南アフリカ, オーストラリア, ニニージーランドなどの畜産先進国で活発に行なわれて いることは，ここで紹介したとおりである。かが国にお いてもこの種の研究に関心を持たれる研究者が益々增え ることを期待してやまない。

最後に本総説を書く機会を与えていただいた三重大学 生物資源学部座野貞夫教授並びに東北大学農学部佐々木 康之教授に厚くお゙礼申し上げます。

\section{文献}

1) Asmundson, R.V. and W.J. Kelly, Isolation and characterization of plasmid DNA from Ruminococcus. Curr. Microbiol., 16 : 97-100. 1987.

2) Barros, M.E.C. and J.A. Thomson, Cloning and expression in Escherichia coli of a cellulase gene from Ruminococcus flavefaciens. J. Bacteriol., 169: 1760-1762. 1987.

3) Beguin, P., J. Millet, O. Grepinet, A. Navarro, M. JuY, A. AmIt, R. POLJaK and J.P. AUBERT, The cel (cellulose degradation) genes of Clostridium thermocellum. Biochemistry and genetics of cellulose degradation. (J.P. AUBERT, P. Beguin and J. MrLLET eds.) 267-282. Academic Press Inc. San Diego. 1988.

4) BERGER, E., W.A. JoNEs, D.T. Jones and D.R. Woons, Cloning and sequencing of an endoglucanase (end 1) gene from Butyrivibrio fibrisolvens H17 c. Mol. Gen. Genet., 219 : 193 198. 1989.

5) Berger, E., W.A. Jones, D.T. Jones and D.R. Woons, Sequencing and expression of a cellodextrinase (ced 1) gene from Butyrivibrio fibrisolvens $\mathrm{H} 17 \mathrm{c}$ cloned in Escherichia coli. Mol. Gen. Genet., 223 : 310-318. 1990.

6) Bhat, S., R.J. Wallace and E.R. $\varnothing_{\text {RSkov, }}$ Adhesion of cellulolytic ruminal bacteria to barley straw. Appl. Environ. Microbiol., 56: 2698-2703. 1990.

7) Cavicchioli, R. and K. Watson, Molecular cloning, expression, and characterization of endoglucanase genes from Fibrobacter succinogenes AR 1. Appl. Environ. Microbiol., $57:$ 359-365. 1991.

8) Cavicchioli, R., P.D. East and K. Watson, endA $A_{\mathrm{s},}$ a novel family $\mathrm{E}$ endoglucanase gene from Fibrobacter succinogenes AR 1. J. Bacteriol., 173: 3265-3268. 1991.

9) Champion, K.M., C.T. Helaszek and B.A. WHITE, Analysis of antibiotic susceptibility and extrachromosomal DNA content of Ruminococcus albus and Ruminococcus flavefaciens. Can. J. Microbiol., 34 : 11091115. 1988.

10) Cheng, K.J., C.W. Forsberg, H. Minato and J.W. Costerton, Microbial ecology and physiology of feed degradation within the rumen: Proceedings of the seventh international symposium on ruminant physiology. (T. TsudA, Y. SASAKI and R. KAWASAKI eds) 595-624. Academic Press, Inc. San Diego and the Government of Canada. 1991.

11) CotтA, M.A., Amylolytic activity of selected species of ruminal bacteria. Appl. Environ. Microbiol., 54: 772-776. 1988.

12) Crosey, B., B. Collier, D.Y. Thomas, R.M. Teather and J.D. ERfle, Cloning and expression in Escherichia coli of cellulase genes from Bacteroides succinogenes: Fifth Canadian Bioenergy $R$ \& D Seminar. (S. Hasnarn eds) 573 576. Elsevier Applied Science Publications, Amsterdam, Netherlands. 1984. 
13) Deguchi, H., Y. Watanabe, T. Sasaki, T. Matsuda, S. Shimizu and K. Ohmiya, Purification and properties of the endo-1, 4- $\beta$-glucanase from Ruminococcus albus and its gene products in Escherichia coli. J. Ferment. Bioeng., 71 : 221-225. 1991.

14) Dower, W.J., J.F. Milier and C.W. RAGSDALE, High efficiency transformation of $E$. coli by high voltage electroporation. Nucleic Acids Res., 16 : 6127 6145. 1988.

15) Erfle, J.D., R.M. Teather, P.J. WoOD and J.E. IRVIN, Purification and properties of a $1,3-1,4-\beta-D-g l u c a n a s e$ (lichenase, 1 , 3-1, 4- $\beta$-D-glucan 4-glucanohydrolase, EC 3.2.1.73) from Bacteroides succinogenes cloned in Escherichia coli. Biochem. J., 255 : 833-841. 1988.

16) Erfle, J.D. and R.M. Teather, Isolation and properties of a $(1,3)-\beta-D-g l u c a n a s e$ from Ruminococcus flavefaciens. Appl. Environ. Microbiol., 57 : 122-129. 1991.

17) Finnt, H.J., A.M. Thomson and J. Bisset, Plasmid-associated transfer of tetracycline resistance in Bacteroides ruminicola. Appl. Environ. Microbiol., 54: 855-860. 1988.

18) Flint, H.J., C.A. McPherson and J. BIsset, Molecular cloning of genes from Ruminococcus flavefaciens encoding xylananse and $\beta(1-3,1-4)$ glucanase activities. Appl. Environ. Microbiol., 55 : 1230-1233. 1989.

19) Forsberg, C.W., B. Crosby and D.Y. Thomas, Potential for manipulation of the rumen fermentation through the use of recombinant DNA techniques. J. Anim. Sci., 63: 310-325. 1986.

20) Fukumori, F., N. Sashihara, T. Kudo and K. Horikoshi, Nucleotide sequences of two cellulase genes from alkalophilic Bacillus sp. strain $\mathrm{N}-4$ and their strong homology. J. Bacteriol., 168: 479 485. 1986.

21) Gardner, R.M., K.C. Doerner and B.A. White, Purification and characterization of an exo- $\beta-1,4-$ glucanase from Ruminococcus flavefaciens FD-1. J. Bacteriol., 169 : 4581-4588. 1987.

22) Gilkes, N.R., B. Henrissat, D.G. KilBURN, R.C. MHLLR, Jr. and R.A.J. WARREN, Domains in microbial $\beta-1,4$ glycanases: sequence conservation, function, and enzyme families. Microbiol. Rev., 55 : 303-315. 1991.

23) Gong, J., R.Y.C. Lo and C.W. ForsberG,
Molecular cloning and expression in Escherichia coli of a cellodextrinase gene from Bacteroides succinogenes S 85. Appl. Environ. Microbiol., 55 : 132-136. 1989.

24) Gong, J. and C.W. Forsberg, Factors affecting adhesion of Fibrobacter succinogenes subsp. succinogenes $\mathrm{S} 85$ and adherence-defective mutants to cellulose. Appl. Environ. Microbiol., 55 : 3039-3044. 1989.

25) Hall, J., G.P. Hazlewood, P.J. Barker and H.J. GILBERT, Conserved reiterated domains in Clostridium thermocellum endoglucanases are not essential for catalytic activity. Gene, 69: 29-38. 1988.

26) Hazlewood, G.P., K. Davidson, J.I, Laurie, M.P.M. Romaniec and H.J. GilBERT, Cloning and sequencing of the celA gene encoding endoglucanase A of Butyrivibrio fibrisolvens strain A 46. J. Gen. Microbiol., 136 : 2089-2097. 1990.

27) Hespelt, R.B., Biotechnology and modifications of the rumen microbial ecosystem. Proc. Nutr. Soc., 46: 407-413. 1987.

28) Hespelt, R.B., R. Wolf and R.J. Bothast, Fermentation of xylans by Butyrivibrio fibrisolvens and other ruminal bacteria. Appl. Environ. Microbiol., 53 : 2849-2853. 1987.

29) Hespell, R.B. and P.J. O'Bryan-shah, Esterase activities in Butyrivibrio fibrisolvens strains. Appl. Environ. Microbiol., 34 : 1917-1922. 1988.

30) Hespeld, R.B. and T.R. Whitehead, Conjugal transfer of $\operatorname{Tn} 916$, Tn $916 \Delta \mathrm{E}$, and $\mathrm{pAM} \beta 1$ from Enterococcus faecalis to Butyrivibrio fibrisolvens strains. Appl. Environ. Microbiol, 57 : 2703-2709. 1991.

31) Howard, G.T. and B.A. White, Molecular cloning and expression of cellulase genes from Ruminococcus albus 8 in Escherichia coli bacteriophage $\lambda$. Appl. Environ. Microbiol., 54 : 1752-1755. 1988.

32) Hu, Y.J., D.C. Smith, K.J. Cheng and C.W. Forsberg, Cloning of a xylanase gene from Fibrobacter succinogenes 135 and its expression in Escherichia coli. Can. J. Microbiol., 37 : 554-561. 1991.

33) HuAng, L. and C.W. Forsberg, Isolation of a cellodextrinase from Bacteroides succinogenes. Appl. Environ. Microbiol., 53: 1034-1041. 1987.

34) Huang, L. and C.W. Forsberg, Purifica- 
tion and comparison of the periplasmic and extracellular forms of the cellodextrinase from Bacteroides succinogenes. Appl. Environ. Microbiol., 54:1488-1493. 1988.

35) Huang, L., C.W. Forsberg and D.Y. Thomas, Purification and characterization of a chloride-stimulated cellobiosidase from Bacteroides succinogenes S85. J. Bacteriol., 170 : 2923-2932. 1988.

36) Irvin, J.E. and R.M. Teather, Cloning and expression of a Bacteroides succinogenes mixed-linkage $\beta$-glucanase ( 1 , $3-1, \quad 4-\beta-\mathrm{D}$-glucane 4-glucanohydrolase) gene in Escherichia coli. Appl. Environ. Microbiol., 54 : 2672-2676. 1988.

37) Joliff, G.J., P. Beguin and J.P. Aubert, Nucleotide sequence of the cellulase gene celD encoding endoglucanase D of Clostridium thermocellum. Nucleic Acids Res., 14 : 8605-8613. 1986.

38) Klieve, A.V., J.F. Hudman and T. BaUCHOP, Inducible bacteriophages from ruminal bacteria. Appl. Environ. Microbiol., 55 : 1630-1634. 1989.

39) Klieve, A.V., K. Gregg and T. Bauchop, Isolation and characterization of lytic phages from Bacteroides ruminicola ss brevis. Curr. Microbiol., 23 : 183-187. 1991.

40) Kudo, H., K.J. Cheng and J.W. CosterTON, Electron microscopic study of the methylcellulose-mediated detachment of cellulolytic rumen bacteria from cellulose fibers. Can J. Microbiol., 33: 267-272. 1987.

41) Lamed, R., J. Naimark, E. Morgenstern and E.A. BAYER, Specialized cell surface structures in cellulolytic bacteria. J. Bacteriol., 169 : 3792-3800. 1987.

42) Lewin, B., Genes IV. 451-462. Oxford Univ. Press, New York and Cell Press, Cambridge. 1990.

43) Luchansky, J.B., P.M. Muriana and T.R. KLAENHAMMER, Application of electroporation for transfer of plasmid DNA to Lactobacillus, Lactococcus, Leuconostoc, Listeria, Pediococcus, Bacillus, Staphylococcus, Entercoccus and Propionibacterium. Mol. Microbiol., 2 : 637-646. 1988.

44) ManN, S.P., G.P. Hazlewood and C.G. ORPIN, Characterization of a cryptic plasmid (pOM 1) in Butyrivibrio fibrisolvens by restriction endonuclease analysis and its cloning in Escherichia coli. Curr. Microbiol., 13 : 17-22. 1986.

45) Mannarelli, B.M., S. Evans and D. Lee, Cloning, sequencing, and expression of a xylanase gene from the anaerobic ruminal bacterium Bulyrivibrio fibrisolvens. J. Bacteriol., 172 : 4247-4254. 1990.

46) MarTin, S.A. and D.E. AKIn, Effect of phenolic monomers on the growth and $\beta$-glucosidase activity of Bacteroides ruminicola and on the carboxymethylcellulase, $\beta$-glucosidase, and xylanase activities of Bacteroides succinogenes. Appl. Environ. Microbiol., 54 : 3019-3022. 1988.

47) Martin, S.A. and R.G. Dean, Characterization of a plasmid from the ruminal bacterium Selenomonas ruminantium. Appl. Environ. Microbiol., 55 : 3035-3038. 1989.

48) Matsushita, O., J.B. Russell and D.B. Wirson, Cloning and sequencing of a Bacteroides ruminicola $\mathrm{B}_{1} 4$ endoglucanase gene. J. Bacteriol., 172 : 3620-3630. 1990.

49) Matsushita, O., J.B. Russell and D.B. WILSON, A Bacteroides ruminicola 1, 4 $\beta$ - $D$-endoglucanase is encoded in two reading frames. J. Bacteriol., 173:69196926. 1991.

50) McDermid, K.P., C.R. Mackenzie and C. W. ForsBERG, Esterase activities of Fibrobacter succinogenes S 85. Appl. Environ. Microbiol., 56 : 127-132. 1990.

51) McGavin, M. and C.W. Forsberg, Isolation and characterization of endoglucanases 1 and 2 from Bacteriodes succinogenes S 85. J. Bacteriol., 170 : 2914-2922. 1988.

52) McGavin, M. and C.W. Forsberg, CataIytic and substrate-binding domains of endoglucanase 2 from Bacteroides succinogenes. J. Bacteriol., $171: 3310-3315$. 1989.

53) McGavin, M.J., C.W. Forsberg, B. Crosby, A.W. Bell, D.Dignard and D.Y. Thomas, Structure of the cel-3 gene from Fibrobactor succinogenes S 85 and characteristics of the encoded gene product, endoglucanase 3. J. Bacteriol., $171: 5587-$ 5595. 1989.

54) McGavin, M., J. Lam and C.W. Forsberg, Regulation and distribution of Fibrobacter succinogenes subsp. succinogenes $\mathrm{S} 85$ endoglucanases. Appl. Environ. Microbiol., 56 : 
1235-1244. 1990.

55) Minato, H. and T. Suto, Technique for fractionation of bacteria in rumen microbial ecosystem. II. Attachment of bacteria isolated from bovine rumen to cellulose powder in vitro and elution of bacteria attached therefrom. J. Gen. Appl. Microbiol., 24: 1-16. 1978.

56) Montgomery, L., B.A. Flesher and D.A. STAHL, Transfer of Bacteroides succinogenes (Hungate) to Fibrobacter gen. nov. as Fibrobacter succinogenes comb. nov. and description of Fibrobacter intestinalis sp. nov. Int. J. Sys. Bacteriol., 38: 430435. 1988.

57) Morris, E.J. and O.J. COLE, Relationship between cellulolytic activity and adhesion to cellulose in Ruminococcus albus. J. Gen. Microbiol., 133 : 1023-1032. 1987.

58) Morris, E.J., Characteristics of the adhesion of Rumincoccus albus to cellulose. FEMS Microbiol. Lett., 51 : 113118. 1988 .

59) Morrison, M., R.I. Mackie and A. KISTNER, 3-Phenylpropanoic acid improves the affinity of Ruminococcus albus for cellulose in continuous culture. Appl. Environ. Microbiol., $56: 3220-3222.1990$.

60) Murphy, N., D.J. McConnel and B.A. Cantwell, The DNA sequence of the gene and genetic control sites for the excreted $B$. subtilus enzyme $\beta$-glucanase. Nucleic Acids Res., 12 : 5355-5367. 1984.

61) Ning, Z., G.T. Atrwood, R.A. Lockington and J.D. BroOKer, Genetic diversity in ruminal isolates of Selenomonas ruminantium. Curr. Microbiol., 22 : 279-284. 1991.

62) Ogimoto, K. and S. Imar, Atlas of rumen microbiology. 71-125. Japan Scientific Societies Press, Tokyo. 1981.

63) Onmiya, K., M. Shimizu, M. Taya and S. Shimizu, Purification and properties of cellobiosidase from Ruminococcus albus. J. Bacteriol., 150 : 407-409. 1982.

64) Ohmiya, K., M. Shirai, M. Kurachi and S. SHImIzU, Isolation and properties of $\beta$-glucosidase from Ruminococcus albus. J. Bacteriol, 161: 432-434. 1985.

65) Оhмiya, K., K. Maeda and S. Shimizu, Purification and properties of endo- $(1,4)-$ $\beta$-glucanase from Ruminococcus albus. Carbohydr. Res., 166: 145-155. 1987.

66) Ohmiya, K., K. Nagashima, T, Kajino, E.
Goto, A. Tsukada and S. Shimizu, Cloning of the cellulase gene from Ruminococcus albus and its expression in Escherichia coli. Appl. Environ. Microbiol., 54: 15111515. 1988.

67) Ohmiya, K., T. Kajino, A. Kato and S. Shimizu, Structure of a Ruminococcus albus endo-1, 4 - $\beta$-glucanase gene. J. Bacteriol., 171 : 6771-6775. 1989.

68) Ohmiya, K., T. Takano and S. Shrmizu, DNA sequence of a $\beta$-glucosidase from Ruminococcus albus. Nucleic Acids Res., 18: 671. 1990.

69) Ohmiy a, K., C. Hoshino and S. Shimizu, Novel plasmids responsible for the cellulose utilizing ability of Ruminococcus albus. Jpn. J. Zootech. Sci,, 61: 557-561. 1990.

70) Ohmiy a, K., H. Deguchi and S. Shimizu, Modification of the properties of a Ruminococcus albus endo-1, 4- $\beta$-glucanase by gene truncation. J. Bacteriol., 173: 636641. 1991.

71) Poole, D.M., G.P. Hazlewood, J.I. LauRIE, P.J. BARKER and H.J. GILBERT, Nucleotide sequence of the Ruminococcus albus SY 3 endoglucanase genes celA and celB. Mol. Gen. Genet., 223 : 217-223. 1990.

72) Rasmussen, M.A., B.A. White and R.B. Hespell, Improved assay for quantitating adherence of ruminal bacteria to cellulose. Appl. Environ. Microbiol., 55 : 2089-2091. 1989.

73) Rusell, J.B. and D.B. Wilson, Potential oppotunities and problems for genetically altered rumen microorganisms. J. Nutr., 118: $271-279.1988$.

74) Sakka, K., S. Furuse and K. Shimada, Cloning and expression in Escherichia coli of thermophilic Clostridium sp. F1 genes related to cellulose hydrolysis. Agric. Biol. Chem., 53 : 905-910. 1989.

75) Schwarz, W.H., S. Schimming, K.P. RUCKNagel, S. Burgschwaiger, G. Kreil and W.L. Straudenbauer, Nucleotide sequence of the celC gene encoding endoglucanase $\mathrm{C}$ of Clostridium thermocellum. Gene, 63: 23-30. 1988.

76) SнAн, H.N. and M.D. Collins, Prevotella, a new genus to include Bacteroides melaninogenicus and related species formerly classified in the genus Bacteroides. Int. J. Syst. Bacteriol., 40 : 205-208. 1990. 


\section{植物織維分解ルーメン細囷における遺伝子工学}

77) Sewell, G.W., E.A. Utt, R.B. Hespell, K.F. MACKenzIE and L.O. INGRAM, Identification of the Butyrivibrio fibrisolvens $\mathrm{xy}$ losidase gene $(x y l B)$ coding region and its expression in Escherichia coli. Appl. Environ. Micriobiol., 55 : 306-311. 1989.

78) Shommaker, N.B., K.L. Anderson, S.L. Smithson, G.R. WANG and A.A. SAlyers, Conjugal transfer of a shuttle vector from the human colonic anaerobe Bacteriodes uniformis to the ruminal anaerobe Prevotella (Bacteroides) ruminicola $\mathrm{B}_{1} 4$. Appl. Environ. Microbiol., 57 : 2114-2120. 1991.

79) Sipat, A., K.A. Taylor, R.Y.C. Lo, C.W. Forsberg and P.J. KreLl, Molecular cloning of a xylanase gene from Bacteroides succinogenes and its expression in Escherichia coli. Appl. Environ. Microbiol., 53 : 477-481. 1987.

80) Smith, D.C. and C.W. ForsberG, $\alpha$-Glucuronidase and other hemicellulase actibities of Fibrobacter succinogenes $\mathrm{S} 85$ grown on crystalline cellulose or ballmilled barley straw. Appl. Environ. Microbiol., 57 : 3552-3557. 1991.

81) StewART, C.S. and H.J. Flint, Bacteroides (Fibrobacter) succinogenes, a cellulolytic anaerobic bacterium from the gastrointerstinal tract. Appl. Microbiol. Biotechnol., 30 : 433-439. 1989.

82) Takano, M., R. Moriyama and K. OhmiYa, Structure of a $\beta$-glucosidase gene from Ruminococcus albus and properties of the translated product. J. Ferment. Bioeng., 73: 79-88. 1992.

83) Taylor, K.A., B. Crosby, M. McGavin, C.W. Forsberg and D.Y. Thomas, Characteristics of the endoglucanase encoded by a cel gene from Bacteroides succinogenes expressed in Escherichia coli. Appl. Environ. Microbiol., 53: 41-46. 1987.

84) Teather, R.M., Isolation of plasmid DNA from Butyrivibrio fibrisolvens. Appl. Environ. Microbiol., 43 : 298-302. 1982.

85) Teather, R.M., Application of gene manipulation to rumen microflora. Can. J. Anim. Sci., 65 : 563-574. 1985.

86) Teather, R.M. and J.D. ERFLE, DNA sequence of a Fibrobactor succinogenes mixed-linkage $\beta$-glucanase $(1,3-1,4-\beta$-Dglucan 4-glucanohydrolase) gene. J. Bacteriol., 172: 3837-3841. 1990.
87) Teather, R.M. and K. Ohmiya, Molecular genetics of rumen cellulase system. Phy siological aspects of digestion and metabolism in ruminants: Proceedings of the seventh international symposium on ruminant physiology. (T. TSUDA, Y. SASAKI and R. Kawasaki eds) 701-718. Academic Press, Inc. San Diego and the Government of Canada. 1991.

88) Thomson, A.M. and H.J. Flint, Electroporation induced transformation of Bacteroides ruminicola and Bacteroides uniformis by plasmid DNA. FEMS Microbiol. Lett., 61 : 101-104. 1989.

89) Urr, E.A., C.K. EdDy, K.F. Keshav and L.O. InGRAM, Sequencing and expression of the Butyrivibrio fibrisolvens $x y l B$ gene encoding a novel bifunctional protein with $\beta$-D-xylosidase and $a-\mathrm{L}$-arabinofuranosidase activities. Appl. Environ. Microbiol., $57:$ 1227-1234. 1991.

90) Wang, W. and J.A. Thomson, Nucleotide sequence of the celA gene encoding a cellodextrinase of Ruminococcus flavefaciens FD-1. Mol. Gen. Genet., 222 : 265-269. 1990.

91) WARE, C.E., T. BAuchop and K. GregG, The isolation and comparison of cellulase genes from two strains of Ruminococcus albus. J. Gen. Microbiol., 135 : 921-930. 1989.

92) Watanabe, Y., R. Moriyama, T. Matsuda, $S$. Shimizu and $K$. Ohmiya, Purification and properties of the endo- $1,4-\beta$-glucanase III from Ruminococcus albus. J. Ferment. Bioeng., 73 : 54-57. 1992.

93) Weiss, R.B. and J.A. Gallant, Frameshift suppression in aminoacyl-tRNA limited cells. Genetics, 112: 727-739. 1986.

94) Weiss, R.B., D.M. Dunn, A.E. DahlberG, J.F. Atkins and R.F. Gesteland, Reading frame switch caused by base pair formation between the $3^{\prime}$ end of $16 \mathrm{~S}$ rRNA and the mRNA during elongation of protein synthesis in Escherichia coli. EMBO J., 7 : 1503-1507. 1988.

95) Whitehead, T.R. and R.B. Hespell, Cloning and expression in Escherichia coli of a xylanase gene from Bacteroides ruminicola 23. Appl. Environ. Microbiol., 55 : 893-896. 1989.

96) Whitehead, T.R. and R.B. Hespell, Heterologous expression of the Bacteroides 
ruminicola xylanase gene in Bacteroides fragilis and Bacteroides uniformis. FEMS Microbiol. Lett., 66 : 61-66. 1990.

97) Whitehead, T.R., M.A. Cotta and R.B. Hespell, Introduction of the Bacteroides ruminicola xylanase gene into the Bacteroides thetaiotaomicron chromosome for production of xylanase activity. Appl. Environ. Microbiol, $57: 277-282.1991$.

98) WhItehead, T.R. and D.A. LeE, Cloning and comparison of xylanase genes from ruminal and colonic Bacteroides species.
Curr. Microbiol., 23 : 15-19. 1991.

99) WILLIAMS, A.G. and S.E. WITHERS, The production of plant cell wall polysaccharide-degrading enzymes by hemicellulolytic rumen bacterial isolates grown on a range of carbohydrate substances. J. Appl. Bacteriol., 52 : 377-387. 1982.

100) Woods, J.R., J.F. Hudman and K. GregG, Isolation of an endoglucanase gene from Bacteroides ruminicola subsp. brevis. J. Gen. Microbiol., 135 : 2543-2549. 1989. 